149 Meet the APSA Officers and Council

155 2019 Annual Meeting Announcment

156 Additional 2018 Annua Meeting Highlights

1602019 APSA Award Nominations

161 Washington Insider
162 Members of the Month

163 International

165 Gazette

168 Organized Section

Update

194 APSA Contributors

\title{
Meet the APSA Officers and Council
}

T he following officers and council members were elected in 2018 by the APSA Council. APSA welcomes the new officers and council members.

\section{PRESIDENT}

\section{Rogers M. Smith}

Rogers M. Smith is Christopher H. Browne Distinguished Professor of Political Science at the University of Pennsylvania. His BA is from James Madison College, Michigan State University, and his MA and $\mathrm{PhD}$ degrees are from Harvard University. Trained in the history of political thought and American constitutional law and politics, his scholarship blends empirical and normative concerns focused on the politics of citizenship and identity, espe-

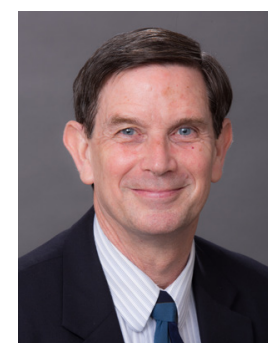
cially issues of race, gender, and religion in American constitutional development. $\mathrm{He}$ is the author or coauthor of seven books, including Political Peoplehood (2015) and Civic Ideals (1997), which won the APSA's Bunche, Easton, and Greenstone awards. He has authored or coauthored over 90 articles in journals and edited volumes, including the American Political Science Review, Journal of Politics, Studies in American Political Development, and Political Theory. He received the Law and Courts Section's 2004 Wadsworth Award for his APSR article “The 'New Institutionalism' and the Future of Public Law." Smith has supervised $39 \mathrm{PhD}$ theses and received Penn's Provost Award for Distinguished PhD Mentoring; Lindback Award for Distinguished Teaching; Dean's Award for Mentoring Undergraduate Research; and a Distinguished Undergraduate Teaching Prize from Yale, where he taught from 1980 to 2001.
At Penn he served as department chair from 2003 to 2006 and is now associate dean for social sciences. He founded the Penn Program on Democracy, Citizenship, and Constitutionalism in 2006 and has since directed it. He also cofounded the Teachers Institute of Philadelphia, a universitypublic school partnership. His APSA roles include chair of the Politics and History Organized Section, 2001-2002; program chair of Constitutional Law and Jurisprudence, 2001-2002; cochair of the Task Force on Graduate Education, 2002-2003; member of the Committee on the Status of Blacks in the Profession, 2004-2007; Council Member, 2005-2006; chair of the Perspectives on Politics editor search committee, 2008; Vice President, 2008-2009; member of the Task Force on Public Engagement, 2013-2014; and cochair of the Migration and Citizenship Section, 2013-2015. He received the Frank J. Goodnow Award in 2010. He is a Fellow of the American Academy of Arts and Sciences, the American Academy of Political and Social Science, and the American Philosophical Society.

\section{PRESIDENT-ELECT}

\section{Paula D. McClain}

Paula D. McClain is professor of political science and professor of public policy at Duke University, where she also serves as dean of the Graduate School and vice provost for graduate education. She has also directed APSA's Ralph Bunche Summer Institute at Duke for more than twenty years.

McClain studies racial minority group politics-particularly interminority political and social compe-

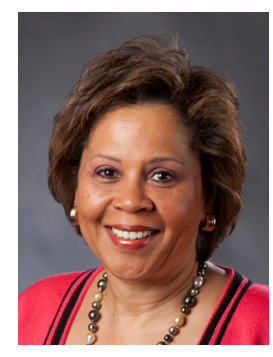
tition. She has published in numerous journals, including the American Political Science Review, the Journal of Politics, and
Politics, Groups and Identities. She also has coauthored three books:

- American Government in Black and White: Diversity and Democracy, Third Edition (Oxford University Press, 2017) which won APSA's Race, Ethnicity and Politics section Best Book Award for a book published in 2010;

- “Can't We All Get Along?" Racial and Ethnic Minorities in American Politics, Seventh Edition (Westview Press 2017) which won the 1996 Gustavus Myers Center for the Study of Human Rights in North America Award for Outstanding Scholarship on the Subject of Intolerance; and

- Race, Place and Risk: Black Homicide in Urban America (SUNY Press 1990) which won the National Conference of Black Political Scientists' 1995 Best Book Award for a previously published book that has made a substantial and continuing contribution.

McClain has served as president of the Midwest Political Science Association (MPSA), the Southern Political Science Association (SPSA), and the National Conference of Black Political Scientists. She has also been vice president of APSA, MPSA, and SPSA, as well as program chair or cochair for the annual meetings of all three organizations. She was also a vice president and program cochair for the 2003 International Political Science Association World Congress.

In 2014, McClain was elected to the American Academy of Arts and Sciences. Her numerous honors include the Duke University Blue Ribbon Diversity Award (2012), the Graduate School Mentoring Award (2010), the Frank J. Goodnow Award for contributions to the profession of political science (2007), a Meta Mentoring Award from the Women's Caucus for 
Political Science of the APSA (2007), the Manning Dauer Award from SPSA (2015), and the Midwest Women's Caucus of Political Science Outstanding Professional Achievement Award (2017).

\section{PAST-PRESIDENT}

\section{Kathleen Thelen}

Kathleen Thelen is Ford Professor of Political Science at MIT. She received her BA from the University of Kansas and her PhD from the University of California, Berkeley. Thelen is a comparativist whose work focuses on the origins and evolution of political-economic institutions in the rich democracies. Her latest book, Varieties of Liberalization and the New Politics of Social Solidarity (2014), received the Barrington Moore Prize and was co-

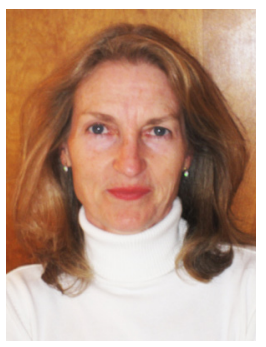
winner of Best Book in the European Politics and Society Section. A previous work, How Institutions Evolve, was selected for the 2006 Mattei Dogan Award, and shared the 2005 Woodrow Wilson Foundation Award. Thelen has also contributed to the literature on institutional analysis, including Advances in Comparative Historical Analysis (2015) and Explaining Institutional Change (2010), both coedited with James Mahoney, Beyond Continuity (2005, with Wolfgang Streeck) and Structuring Politics (1992, with Sven Steinmo). Her article "Historical Institutionalism in Comparative Politics" remains the most cited and most downloaded contribution to the Annual Review of Political Science. Her work has also appeared in a number of journals, including World Politics, Comparative Political Studies, and Politics \& Society, among others.

Thelen has been awarded fellowships from the Institute for Advanced Study (Berlin), Radcliffe Institute, Oxford University, the Max-Planck-Society, and the American-Scandinavian Foundation, among others. She is a Permanent External Scientific Member of the Max Planck Institute for the Study of Societies, and has held visiting appointments in Europe (Sweden, UK, France, Denmark) and Latin America (Mexico, Argentina). She was chair of the Council for European Studies (20022006) and President of the Society for the Advancement of Socio-Economics (20082009). Along with Erik Wibbels, she edits the Cambridge University Press Series in
Comparative Politics. She is a member of the American Academy of Arts and Sciences (since 2015) and its German equivalent, the Berlin-Brandenburg Academy of Sciences (since 2009).

Thelen has been active in the association, most recently serving as President-Elect. In the past she served as a member of APSA Council and as Treasurer. She has also served on numerous committees and as an officer in several Organized Sections-Comparative Politics (president), Politics and History (president), Qualitative and Multi-Method Research (vice-president), and European Politics and Society (treasurer).

\section{VICE PRESIDENTS (2018-2019) Cathy J. Cohen}

Cathy J. Cohen is the David and Mary Winton Green Professor at the University of Chicago. She formerly served in numerous administrative position at the university, including chair of the Department of Political Science, director of the Center for the Study of Race, Politics and Culture and deputy provost for graduate education. Cohen is the author of two books, The Boundaries of Blackness: AIDS and the Breakdown of

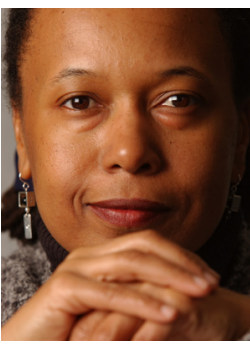
Black Politics (University of Chicago Press) and Democracy Remixed: Black Youth and the Future of American Politics (Oxford University Press). She is also coeditor of the anthology Women Transforming Politics: An Alternative Reader (NYU Press) with Kathleen Jones and Joan Tronto. Her articles have been published in numerous journals and edited volumes including the American Political Science Review, NOMOS, GLQ, Social Text, and the DuBois Review. Cohen has been active in APSA serving on the council, committees, and in numerous other capacities.

Cohen created and currently oversees two major research and public-facing projects: the GenForward Survey and the Black Youth Project. She is the recipient of numerous awards and is coeditor with Frederick Harris of a book series at Oxford University Press entitled Transgressing Boundaries: Studies in Black Politics and Black Communities. In addition to her academic work, Cohen has been politically active, helping to create organizations such as the Audre Lorde Project and Scholars for Social Justice.

\section{Lisa L. Martin}

Lisa L. Martin is professor of political science and associate dean of graduate education at the University of Wisconsin, Madison. Her work focuses primarily on international institutions, international political economy, and international cooperation. Her work has also recently branched off to study gender bias in student evaluations of teaching and the geography of political economy. Current research projects include understanding variation in the exercise of informal influence in international organizations; the spatial distribution of disputed maritime borders; and

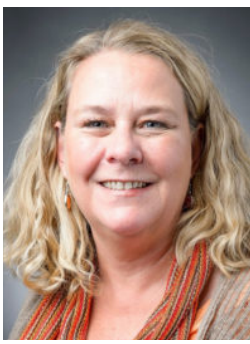
political influences on the geographical distribution of foreign assistance within recipient countries. She has been a Guggenheim Fellow, and is the author of Democratic Commitments: Legislatures and International Cooperation (Princeton University Press, 200o) and Coercive Cooperation: Explaining Multilateral Economic Sanctions (Princeton University Press, 1992). She recently edited the Oxford Handbook of the Political Economy of International Trade (2015). She has recently published in International Theory, PS: Political Science \& Politics, and Perspectives on Politics. She has served as editor in chief of International Organization and associate editor of Quarterly Journal of Political Science. She has served in numerous capacities for the APSA, including secretary, Annual Meeting program cochair, chair of the Publications Committee, and division chair for the Annual Meeting.

\section{Dvora Yanow}

A political ethnographer and interpretive methodologist, I explore the generation and communication of knowing and meaning in policy and organizational settings. I am guest professor in Wageningen University's Department of Social Sciences' Communication, Philosophy, and Technology Subdepartment and affiliated researcher

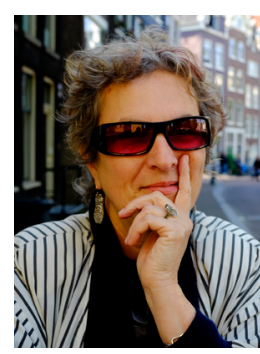
with the "RaceFaceID" research group, University of Amsterdam. There I study state-created categories for raceethnic identity, immigrant integration policies, and 
citizen-making practices. I also investigate research ethics and their regulation; practice studies; and science/technology museums and the idea of science. My publications include Constructing "Race" and "Ethnicity" in America (2003), winner of two awards; "Culture and Organizational Learning" (coauthored; Journal of Management Inquiry 1994), also an award-winner; Interpretive Research Design (2012), with Peregrine Schwartz-Shea, which launched our coedited Routledge Series on Interpretive Methods; and our coedited Interpretation and Method, Second Edition (2014). I have held fellowships at the Rockefeller Foundation's Bellagio Center and the Käte Hamburger Kolleg/Institute for Global Cooperation Research (University of Duisburg-Essen) and several visiting positions, including at the Danish Institute for International Studies, the University of Strasbourg's Institut d'Etudes Politiques, Vienna's Institute for Advanced Studies, the University of ParisDauphine, and Shenyang's Northeastern University (China).

APSA activities have included serving as Executive Council secretary, APSR editorial board member, founding cochair of the Theory, Policy, and Society [now Critical Policy Studies] Conference Group, and cofounder, Executive Committee cochair, and program cochair of the Interpretive Methodologies and Methods Conference Group. At WPSA I have served as council member and founding cochair of two sections: Immigration and Citizenship, and Interpretation and Methods. I created The Methods Café at APSA (2006) and WPSA (2005) with Peri Schwartz-Shea; we codirected the 2009 NSF Workshop on Interpretive Methodologies and Methods. When not at work, I sing early music, folkdance, and try to practice the violin/fiddle.

\section{TREASURER}

\section{Thomas Pepinsky}

Thomas Pepinsky is associate professor and director of undergraduate studies in the department of government at Cornell University. He specializes in comparative politics and international political economy, with a focus on emerging markets and Southeast Asia. $\mathrm{He}$ is the author of Economic Crises and the Breakdown of Authoritarian Regimes: Indonesia and Malaysia in Com- parative Perspective (2009) and coauthor of Piety and Public Opinion: Understanding Indonesian Islam (forthcoming), as well as articles appearing or forthcoming in the American Journal of Political Science, British Journal of Political Science, Journal of Politics, Perspectives on Politics, Comparative Political Studies, World Development, World Politics, and other journals. His past work has been recognized with awards such as the Franklin L. Burdette/Pi Sigma Alpha Award for Best Paper presented at the 2009 APSA annual meeting. He received his $\mathrm{PhD}$ from Yale University in 2007.

Pepinsky has been active in APSA, serving as co-organizer of the Comparative Politics Organized Section for the 2017 Annual Meeting and organizer of the Political Economy Organized Section for the 2013 Annual Meeting. He also serves as a member of the steering committee for the Association for Analytical Learning on Islam and Muslim Societies (aalims.org), and is the founding president of the American Institute for Indonesian Studies and cofounder of the Southeast Asian Research Group (seareg.org). He regularly teaches courses in comparative politics, political economy, Southeast Asian politics, and research methods.

\section{COUNCIL (2018-2021)}

\section{Adam J. Berinsky}

Adam J. Berinsky is the Mitsui Professor of Political Science at MIT. Berinsky received his BA from Wesleyan University in 1992 and his PhD from the University of Michigan in 2000. He is a specialist in the fields of political behavior and public opinion. $\mathrm{He}$ is primarily concerned with questions of representation and the relationship between the mass public and political leaders.

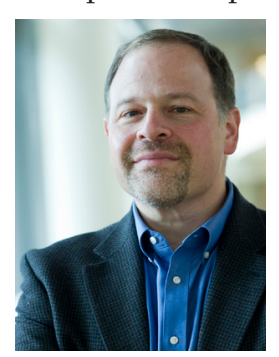

Berinsky is the author of Silent Voices: Public Opinion and Political Participation in America (Princeton University Press, 2004), In Time of War: Understanding American Public Opinion from World War II to Iraq (University of Chicago Press, 2009) and the editor of New Directions in Public Opinion (Routledge, 2017). He has also published articles in many academic journals in political science and psychology.

Berinsky has won several scholarly awards, is the recipient of multiple grants from the National Science Foundation, and was a fellow at the Center for Advanced Study in the Behavioral Sciences. $\mathrm{He}$ currently edits the University of Chicago Press's Chicago Studies in American Politics book series. He is also the founding director of the MIT Political Experiments Research Lab. In 2013 he was awarded the Warren J. Mitofsky Award for Excellence in Public Opinion Research. In 2016, Berinsky was appointed a John Simon Guggenheim Memorial Foundation Fellow to study how political rumors spread and how they can be effectively debunked.

Within APSA, Berinsky has served on the executive councils of the Elections, Public Opinion, and Voting Behavior section and the Experimental Research section. He has also served on award committees for the Political Methodology, Political Psychology, Experimental Research, and Elections, Public Opinion, and Voting Behavior sections.

\section{Ann O'M. Bowman}

Ann O’M. Bowman is professor and Hazel Davis and Robert Kennedy Endowed Chair in Government and Public Service at the Bush School at Texas A\&M University. Prior to joining the Bush School faculty in 2008, she was the James F. and Maude B. Byrnes Professor of Government in

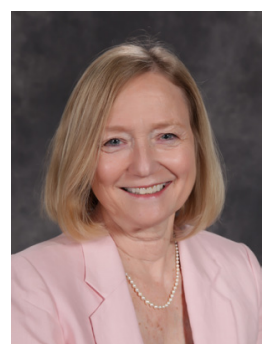
the Department of Political Science at the University of South Carolina. She received her doctorate in political science from the University of Florida. Her areas of expertise include state and local politics and management, intergovernmental relations, public policy, especially the substantive areas of environment, economic development, and land use. She has published more than 50 articles in various scholarly journals; and coauthored or coedited six scholarly books and two textbooks.

She is a fellow of the National Academy of Public Administration and a past-president of the Southern Political Science Association. She has held a Lincoln Government Fellowship at the National League of Cities in Washington, DC and received a Fulbright Distinguished Chair Award to Denmark. She won the Donald C. Stone Award for Research, given by the Section on Intergovernmental Administration and Management of the American Society for Public Administration, and in 2016, she received 
the Daniel Elazar Distinguished Scholar Award from APSA's Federalism and Intergovernmental Relations section.

Currently, Bowman is a member of the editorial advisory council of Publius and the editorial board of Public Administration Review and is a member of the advisory committee for the ICPSR's summer program at the University of Michigan. Previously she served on the editorial boards of the Journal of Politics, Political Research Quarterly, Policy Studies Journal, Journal of Public Administration Research and Theory, Urban Affairs Review, State Politics and Policy Quarterly, Cityscape, and State and Local Government Review. She has been active in APSA for many years, serving at different times as president of three organized sections: Public Policy, Urban Politics, and Federalism \& Intergovernmental Relations.

\section{Julia S. Jordan-Zachery}

Julia S. Jordan-Zachery is professor of public and community service (formerly professor of political science) and director of the Black Studies Program at Providence College. She received her BA (Economics) from Brooklyn College and her PhD from the University of Connecticut. JordanZachery is a Black feminist whose work focuses on public policy, representation, and Black women's political articulations. She published Shadow Bodies: Black Women,

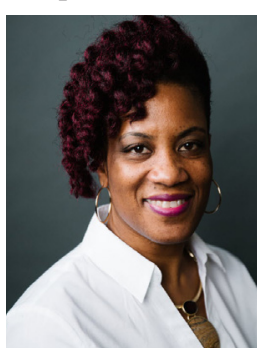
Ideology, Representation, and Politics (2017). A previous work, Black Women, Cultural Images And Social Policy (2009) was selected for the 2010 Association for the Study of Black Women in Politics Anna Julia Cooper Outstanding Book Publication Award and 2009 National Conference of Black Political Scientists W. E B Dubois Best Book Award. Her article "Am I A Black Woman Or A Woman Who Is Black? A Few Thoughts On The Meaning Of Intersectionality" was among the top 50 articles downloaded and top 10 most read articles in Politics \& Gender (October 2015). Her work also appeared in a number of journals, including Politics, Gender and Identities, Journal of Black Sexuality and Relationships, and National Political Science Review, among others.

Jordan-Zachery has been awarded the Joseph R. Accinno Teaching Award. She is president of the Association for Ethnic Studies. Along with Tiffany
Willoughby-Herard, Sharon Wright Austin, Angela K. Lewis, and Duchess Harris, she edits the National Political Science Review. She is a member of the advisory board for the Race, Representation, and American Political Institutions series (Lexington Press).

Jordan-Zachery has been active in the association. She served on various committees: Race Ethnicity and Politics (treasurer), exploratory ad hoc committee for the Journal of Race, Ethnicity, and Politics, and the Mentoring Task Force.

\section{Lori J. Marso}

Lori J. Marso is a feminist political theorist engaging an eclectic field of objects (theory, film, literature) and academic disciplines (on gender, race, postcolonial studies, queer theory, history of political thought). She is the Doris Zemurray Stone Professor of Modern Historical and Literary Studies, and professor of political science at Union College in Schenectady, NY. Marso is the author, coeditor, or editor of several books, most recently Politics with Beauvoir: Freedom in the Encounter (Duke 2017), Politics, Theory, and Film: Critical Encounters with Lars von Trier (coedited with Bonnie Honig, Oxford 2016), and Fifty-One Key Feminist Thinkers (editor, Routledge, 2016). Her articles have

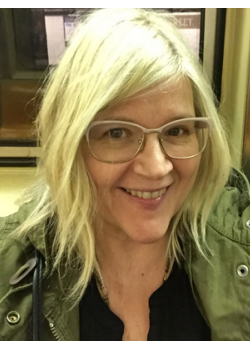
received the Iris Marion Young and Susan Okin Award for Feminist Political Theory, the Contemporary Political Theory Award, the Marion Iris Prize, and the Betty Nesvold Women and Politics Award, and Marso was a recipient of the National Endowment for the Humanities year-long writing fellowship. She was the winner of Union College's campus wide teaching award, the Stilman Prize, in 2011, and has been a finalist for the prize several times.

She worked with several colleagues in political science and political theory when she was the "Critical Exchanges" editor for Contemporary Political Theory from 2014 to 2017, and, with Jill Frank, she is now the consulting editor for Political Theory (editor Lawrie Balfour). Marso has been the chair of the Foundations section of the APSA for the past four years, and before that, was a member of the board. She is also a member of the editorial board of Theory and Event, and Simone de Beauvoir Studies.

Marso has a broad view of the experiences of scholars at several kinds of institutions as she received her undergraduate degree at the University of South Dakota, graduate degrees at London School of Economics and New York University, started her teaching career at University of Texas at San Antonio where she taught for three years, and then moved to Union College where she has taught for 21 years.

\section{Charles Smith}

Charles "Tony" Smith received his $\mathrm{PhD}$ from the University of California, San Diego (2004), his JD from the University of Florida (1987). He is a professor in political science at the University of California, Irvine and associate dean of DCE. His research is grounded in the American judiciary but encompasses work in both comparative and international frameworks using a variety of methodologies. The unifying theme of the research is how institutions and the strategic interaction of political actors relate to the contestation over rights, law and courts, and democracy. He has published The Rise and Fall of War Crimes Trials: from Charles I to Bush II (Cambridge Univer-

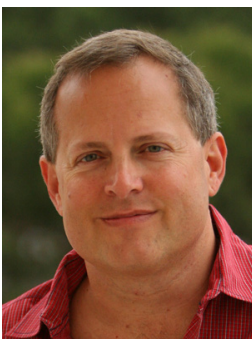
sity Press), Gerrymandering in America: The House of Representatives, The Supreme Court, and The Future of Popular Sovereignty (Cambridge University Press), articles in American Journal of Political Science, Law \& Society Review, Political Research Quarterly, Justice Systems Journal, International Political Science Review, Judicature, Journal of Human Rights, Election Law Journal, Studies in Law, Politics \& Society, Human Rights Review, Journal of International Relations $\mathcal{E}$ Development, and New Political Science, among other journals. He has published chapters in edited volumes with Cambridge University Press, Oxford University Press, Columbia University Press, and University of Pennsylvania Press, among others. He has edited a volume for Routledge and served as guest editor for special issues of the Journal of Human Rights and Human Rights Review. He has served in a variety of roles in APSA including president of the Sexuality \& Politics section, chair of the LGBT Status Committee, and chair of the LGBT Caucus.

\section{Alberto Simpser}

Alberto Simpser is associate professor of political science at the Instituto 
Tecnológico Autónomo de México (ITAM) in his native Mexico City. He has a PhD in

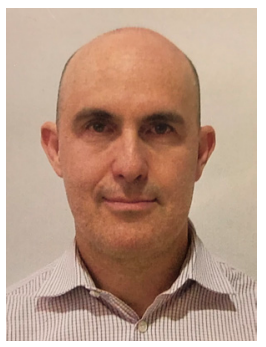
political science from Stanford University. His research interests include the political economy of development, democracy, election fraud, corruption, political culture, and political methodology. Prior to joining ITAM in 2014 he served on the faculty of the University of Chicago's political science department as assistant professor. He was National Fellow at Stanford in 2011 and Fellow at Princeton University's Niehaus Center in 2006.

He is the author of Why Governments and Parties Manipulate Elections (Cambridge University Press 2013), coeditor (with Tom Ginsburg) of Constitutions in Authoritarian Regimes (Cambridge University Press 2014), and has published articles in the American Journal of Political Science, Journal of Politics, Public Opinion Quarterly, Latin American Research Review, and Annual Review of Political Science, among others. His paper "The Intergenerational Transmission of Norms About Corruption" received the 2014 Sage Best Paper Award, and his ongoing work on elections and civic culture received a 2017 Governance Initiative Grant from the Abdul Latif Jameel Poverty Action Lab.

Simpser has served the association as cochair of the Political Economy Division for the 2016 Annual Meeting, committee member for the 2017 McGillivray Best Paper Award of the Political Economy section, and committee member for the 2015 Sage Best Paper Award of the Comparative Democratization section. He currently is a member of the Planning Committee for the Comparative Study of Electoral Systems, and a member of ITAM's Institutional Review Board.

\section{Rocío Titiunik}

Rocío Titiunik is the James Orin Murfin Associate Professor of Political Science at the University of Michigan. She specializes in quantitative methodology for the social sciences, with emphasis on quasiexperimental methods for causal inference and political methodology. Her research interests lie at the intersection of political science, political economy, and applied statistics, particularly on the development and application of quantitative methods to the study of political institutions. Her recent methodological research includes the development of statistical methods

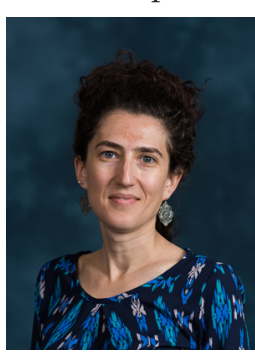
for the analysis and interpretation of treatment effects and program evaluation, with emphasis on regression discontinuity (RD) designs. Her recent substantive research centers on democratic accountability and the role of party systems in developing democracies. Titiunik's work appears in various journals in the social sciences and statistics, including the the American Political Science Review, the American Journal of Political Science, the Journal of Politics, Econometrica, the Journal of the American Statistical Association, and the Journal of the Royal Statistical Society. In 2016, she received the Emerging Scholar Award from the Society for Political Methodology, which honors a young researcher who is making notable contributions to the field of political methodology. She is a member of the leadership team of the Empirical Implications of Theoretical Models (EITM) Summer Institute, member-at-large of the Society for Poltical Methodology, and member of Evidence in Governance and Politics. She is on the editorial board of the American Journal of Political Science and Political Analysis, and is also incoming associate editor for Political Science Research and Methods. Titiunik was born and raised in Buenos Aires, Argentina, where she completed her undergraduate education at the Universidad de Buenos Aires. She received her $\mathrm{PhD}$ in Agricultural and Resource Economics from UC, Berkeley in May 2009. She joined the Michigan faculty as assistant professor in the fall of 2010, after spending one year there as a postdoctoral fellow.

\section{Lisa Wedeen}

Lisa Wedeen is the Mary R. Morton Professor of Political Science and the College and the codirector of the Chicago Center for Contemporary Theory at the University of Chicago. She is also associate faculty in anthropology and a coeditor of the University of Chicago book series, Studies in Practices of Meaning. Her publications include two books: Ambiguities of Domination: Politics, Rhetoric, and Symbols in Contemporary Syria (1999; with a new preface, 2015) and Peripheral Visions: Publics, Power and Performance in Yemen (2008). Among her articles are the following: "Conceptualizing
'Culture': Possibilities for Political Science" (2002); "Concepts and Commitments in the Study of Democracy" (2004), "Ethnography as an Interpretive Enterprise" (2009), "Reflections on Ethnographic Work in Political Science" (2010), "Ideology and Humor in Dark Times: Notes from Syria" (2013), and "Scientific Knowledge, Liberalism, and Empire: American Political Science in the Modern Middle East" (2016). She is the recipient of the David Collier Mid-Career Achievement Award and an NSF fellowship. Her third book, Authoritarian Apprehensions: Ideology, Judgment, and Mourning in Syria, is currently under review at the University of Chicago Press. Based on extensive fieldwork, the book is situated at the intersection of political theory, comparative politics, and cultural anthropology. In addition, she is coediting Conspiracy/Theory (with the anthropologist Joseph Masco, in preparation) and continues to teach in and organize the interpretive social science modules at the Institute for Qualitative Multi-Methods Research in Syracuse. She intends to begin work on a fourth book on violence and representation in the fall, and to complete a book of essays on interpretive social science.

\section{Call for Officer/Council Nominees}

The Nominating Committee welcomes your suggestions for 2019 nominees for president-elect, vice president, and council members. Those wishing to nominate should explain why they believe the person's accomplishments, background, and views would make them a good choice for a leadership position. The committee hopes to nominate a slate of accomplished scholars and practitioners who reflect APSA's diverse membership.

Please send suggestions to nominations@apsanet.org by January 18, 2019. The committee will meet in February 2019 to begin compiling a slate of candidates. The completed slate of nominees will be announced in March and will be put to a member vote via electronic ballot over the summer. Find more information at http://www.apsanet.org/ABOUT/Governance/Elections. 


\section{Continuing Council Members}

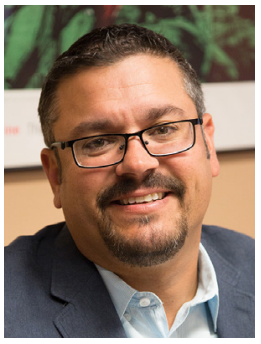

Matt Barreto, University of California, Los Angeles

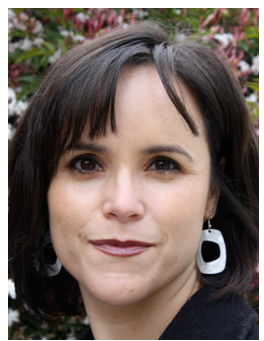

Lisa Garcia-Bedolla, University of California, Berkeley

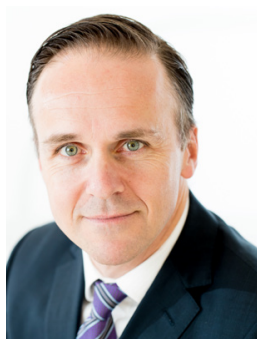

Simon Jackman, University of Sydney

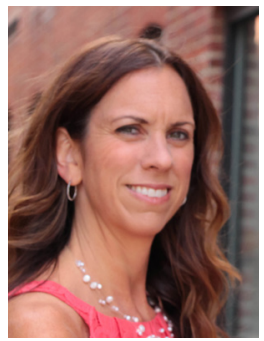

Colleen Shogan, Library of Congress

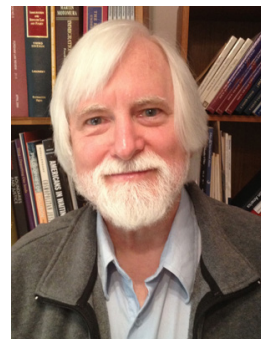

Joseph Carens, University of Toronto

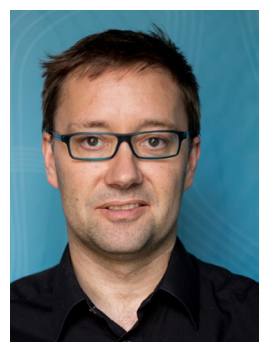

Kristian Gleditsch, University of Essex

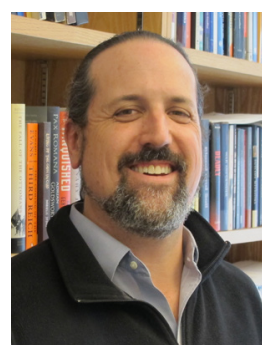

Matthew Kocher, Johns Hopkins University

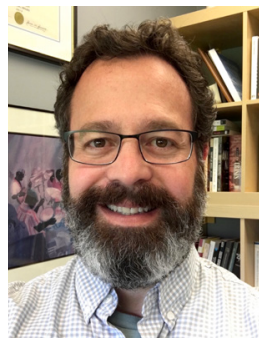

Mark Crescenzi, University of North Carolina, Chapel Hill

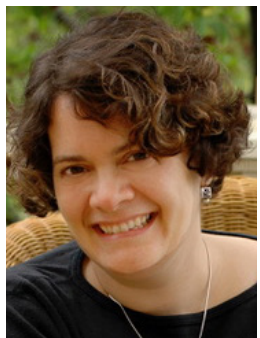

Lilly J. Goren, Carrol University

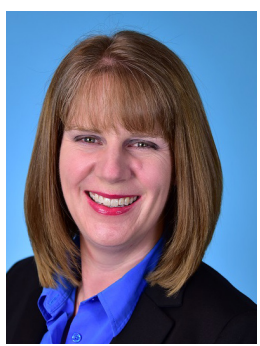

Erin Richards, Cascadia College

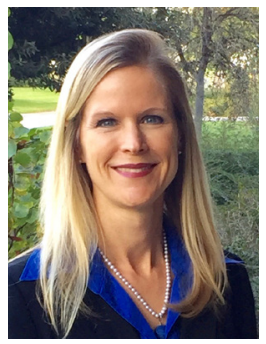

Renée Van Vechten, University of Redlands

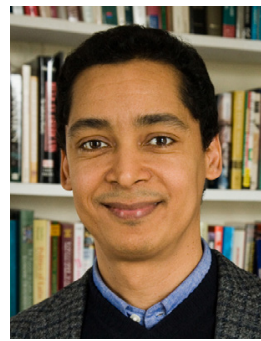

Omar Encarnación, Bard College

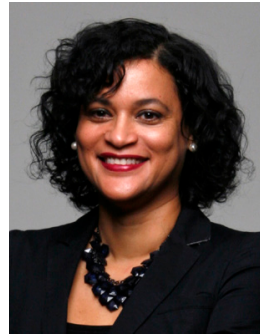

Juliet Hooker, Brown University

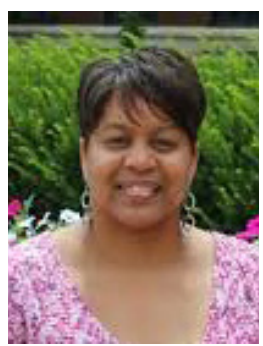

Valeria Sinclair-Chapman, Purdue University

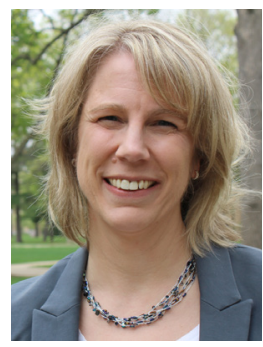

Christina Wolbrecht, University of Notre Dame 